\title{
Yeast Cell Measurement
}

National Cancer Institute

\section{Source}

National Cancer Institute. Yeast Cell Measurement. NCI Thesaurus. Code C74664.

The determination of the number of yeast cells present in a sample. 